
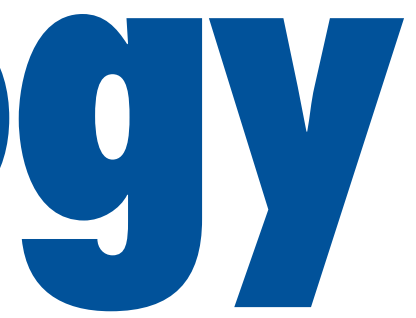

\title{
Highlights in this issue:
}

Treatment with a Novel Hypoxia-Inducible Factor Hydroxylase Inhibitor (TRC160334) Ameliorates Ischemic Acute Kidney Injury

Jamadarkhana, P.; Chaudhary, A.; Chhipa, L.; Dubey, A.; Mohanan, A.; Gupta, R.; Deshpande, $S$.

Obesity, Anthropometric Measures and Chronic Kidney Disease Complications

Navaneethan, S.D.; Kirwan, J.P.; Arrigain, S.; Schreiber, M.J.; Sarnak, M.J.; Schold, J.D.

Tumor Necrosis Factor Receptors: Biology and Therapeutic Potential in Kidney Diseases

Speeckaert, M.M.; Speeckaert, R.; Laute, M.; Vanholder, R.; Delanghe, J.R. 

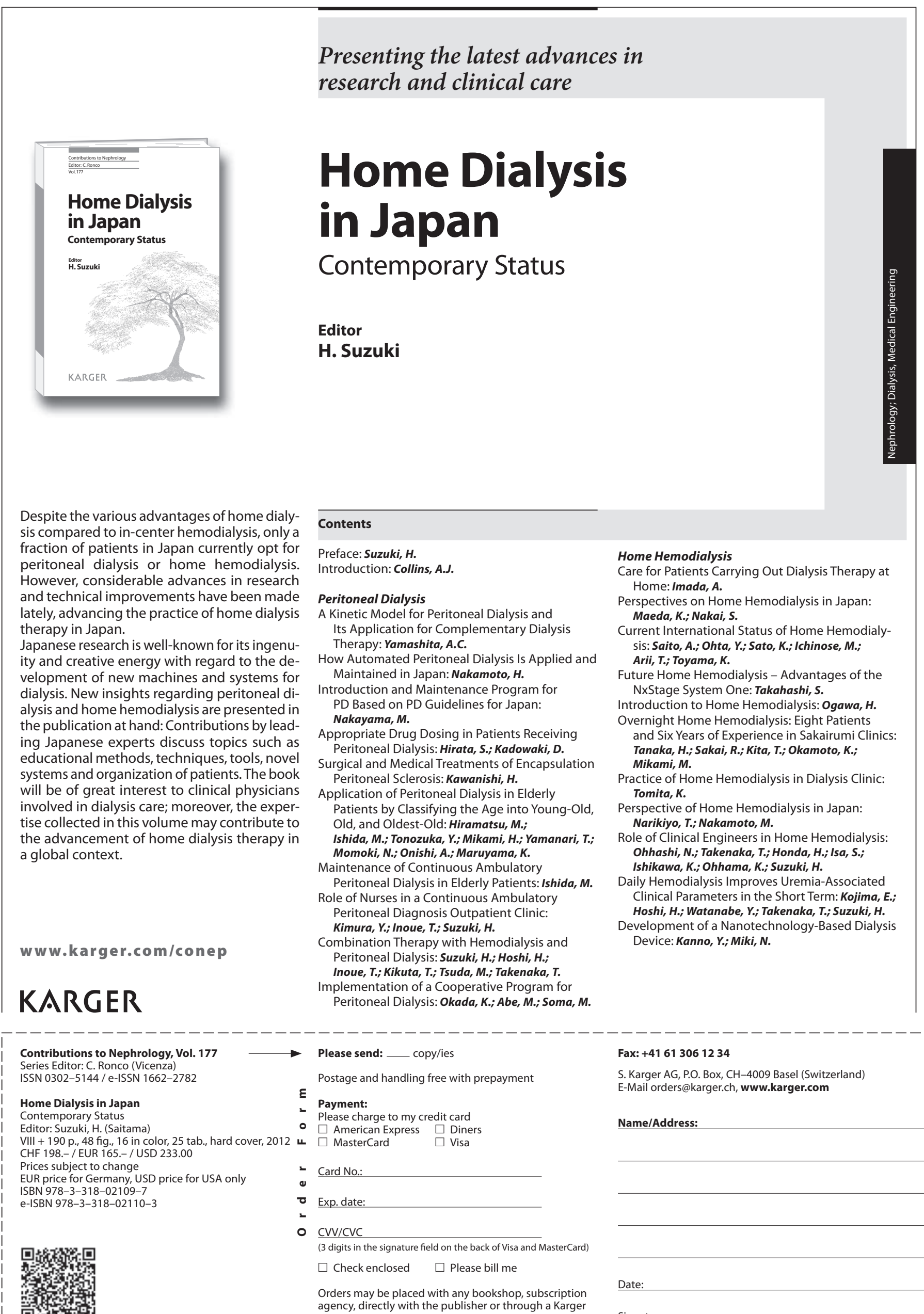

Please send: __ c copy/ies

$\varepsilon$

Payment:

Please charge to my credit card

$\square$ American Express $\square$ Diners

MasterCard $\square$ Visa

Card No.:

Exp. date:

CVV/CVC

(3 digits in the signature field on the back of Visa and MasterCard)

$\square$ Check enclosed $\square$ Please bill me

Orders may be placed with any bookshop, subscription agency, directly with the publisher or through a Karger distributor.
Fax: +41613061234

S. Karger AG, P.O. Box, CH-4009 Basel (Switzerland)

E-Mail orders@karger.ch,www.karger.com

Name/Address: 


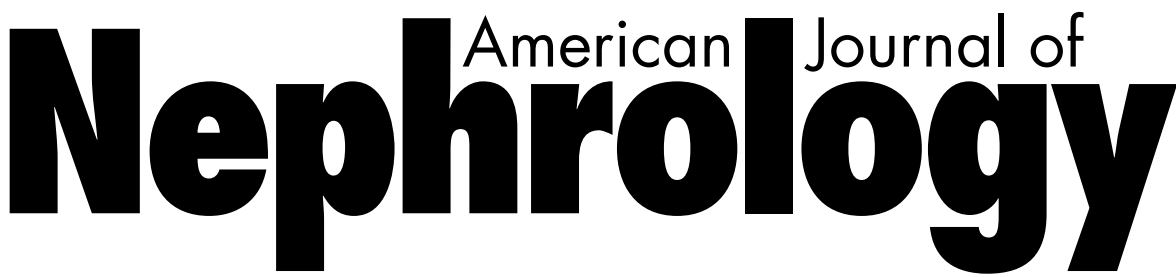

Founded 1981 and edited until 2002 by S.G. Massry

\section{Editor-in-Chief}

G.L. Bakris, Chicago, Ill.

\section{Associate Editors}

R. Agarwal, Indianapolis, Ind.

R.J. Glassock, Los Angeles, Calif.

B. Palmer, Dallas, Tex.

S. Sprague, Evanston, Ill.

M.R. Weir, Baltimore, Md.

\section{Section Editors}

K.C. Abbott, Washington, D.C.

E.A. Ross, Gainesville, Fla.

\section{Administrative Assistant}

B. Brisky, Chicago, Ill.

\section{Editorial Board}

C.K. Abrass, Seattle, Wash.

F. Ali, Chicago, Ill.

J.R. Asplin, Chicago, Ill.

J. Arruda, Chicago, Ill.

P. August, New York, N.Y.

A.S. Awad, Hershey, Pa.

M. Banks, Denver, Colo.

V.K. Bansal, Maywood, Ill.

E. Benedetti, Chicago, Ill.

P. Blake, London, Ontario

M. Braun, Houston, Tex.

E. Brooks, Chicago, Ill.

M. Burnier, Lausanne

D. Capone, Naples

D.F. Catanzaro, New York, N.Y.

J. Cockcroft, Cardiff

M. Cooper, Melbourne

R. Danziger, Chicago, Ill.

J. Daugirdas, Chicago, Ill.
S. D'Souza, London, Ontario

S. El-Dahr, New Orleans, La.

L. Ferder, Ponce, P.R.

B.I. Freedman, Winston-Salem, N.C.

D. Grekas, Thessaloniki

B. Hoppe, Cologne

R. Johnson, Aurora, Colo.

M. Josephson, Chicago, Ill.

K. Kalantar-Zadeh, Torrance, Calif.

J. Kopp, Bethesda, Md.

C.B. Langman, Chicago, Ill.

D. Leehey, Hines, Ill.

S.L. Linas, Denver, Colo.

M.S. Lipkowitz, New York, N.Y.

N. Litbarg, Chicago, Ill.

P.A. McCullough, Novi, Mich.

S. Moe, Indianapolis, Ind.

M. Nangaku, Tokyo

S.B. Nicholas, Los Angeles, Calif.

M.D. Okusa, Charlottesville, Va.

A.J. Peixoto, West Haven, Conn.

A. Portale, San Francisco, Calif.

A. Pozzi, Nashville, Tenn.

W. Proesmans, Leuven

M. Rahman, Cleveland, Ohio

N.M. Rajamannan, Chicago, Ill.

G. Remuzzi, Bergamo

M. Rudnick, Philadelphia, Pa.

R. Sam, San Francisco, Calif.

P. Sarafidis, Thessaloniki

J. Sedor, Cleveland, Ohio

K.C. Siamopoulos, Ioannina

A.K. Singh, Chicago, Ill.

D. Sirivongs, Khon Kaen

H. Suzuki, Saitama

V. Thongboonkerd, Bangkok

C. Tikellis, Melbourne

G. Tsirpanlis, Athens

K. Tuttle, Spokane, Wash.

A.Y.-M. Wang, Hong Kong

A. Whaley-Connell, Columbia, Mo.

J. Yee, Detroit, Mich.
Printed in Switzerland on acid-free and non-aging paper (ISO 9706) by

Reinhardt Druck, Basel
Appearance:

2 volumes per year (12 issues) 


\section{Nephrology}

\section{Submission}

The 'American Journal of Nephrology' only accepts online submissions to:

http://mc.manuscriptcentral.com/ajn

All further technical instructions can be found there.

\section{Conditions}

The journal will not publish articles which have been previously reported at any length or articles being considered for publication elsewhere. The authors must include a statement to this effect in their cover letter. If publication of the data in any form has occurred or is being contemplated, a copy of such publication should be included with the submitted manuscript. Failure to comply with this directive or discovery of any manuscript text, figure(s), or table(s) duplication will result in immediate retraction of the manuscript and/or article and the authors will not be allowed to submit any future manuscripts to this journal for a period of 3 years. Submission of an article for publication implies the transfer of the copyright from the author to the publisher upon acceptance. It is the author's responsibility to obtain permission to reproduce illustrations, tables, etc. from other publications. The manuscript should be written in English and the editors reserve the right to make appropriate corrections in grammar and style. Accepted papers become the permanent property of the 'American Journal of Nephrology' and may not be reproduced by any means, in whole or in part, without the written consent of the publisher. Information concerning financial disclosures (i.e. grants, funding, support, etc.) should be placed at the foot of the title page.

\section{Types of Article for Acceptance}

(1) Original Reports: Representing full sets of completed experiments in the areas of either clinical or basic research that answer a given question. Max. 3,000 words, incl. figures, tables. Maximum 25 references.

a) Transplantation: Manuscripts under this section include both basic and translational topics. Original experimental data are preferred; however, other content will be considered. Guidelines for this category are similar to the other original reports.

b) Patient-oriented, translational research.

c) Laboratory investigation

(2) In-Depth Topic Reviews: Covering a timely topic by experts in the field. Max. 4,500 words, incl. figures, tables. Maximum 60 references.

(3) Nephrology Grand Rounds: We welcome submissions to this section which is designed as a forum for nephrology trainees to discuss disease presentations or cases deserving exceptional merit. The section, however, is intended to extend far beyond the scope of a typical case report. Specifically, we seek case series (e.g. 5 or 6 cases) representing either similar illnesseses or noteworthy unusual manifestations. It is expected that papers will incorporate not only a thorough but also a critical review of the literature. The intent is for senior co-authorships and active involvement on their parts. Submissions are limited to 2,500 words, 1 figure, 1 table and 20 references.

(4) Hot Topics in Nephrology: A Debate (by invitation only): These will be debate forums of unsolved and important clinical issues in nephrology.
There will be a pro and con position and each will consist of 1,500 words with a maximum of 7 key references. The topic will be determined by the editorial board but any proposals are welcomed.

(5) Invited Editorials: The Editor(s) will invite editorials on specifically selected articles. The editorial will have a maximum of 1,000 words and up to 10 references (one of which should be the paper being reviewed). Also, a maximum of one figure or table is allowed.

\section{Conflicts of Interest}

Authors are required to disclose any sponsorship or funding arrangements relating to their research and all authors should disclose any possible conflicts of interest. Conflict of interest statements will be published at the end of the article.

\section{Ethics}

Published research must comply with the guidelines for human studies and animal welfare regulations. Authors should state that subjects have given their informed consent and that the study protocol has been approved by the institute's committee on human research. Further, they should also state that animal experiments conform to institutional standards.

\section{Plagiarism Policy}

Plagiarism is misrepresenting somebody else's published intellectual work-product as your own (Note, this definition excludes 'self-plagiarism'). In short, it is a misuse of source material. Whether intentional or unintentional, plagiarism is a serious violation of the 'American Journal of Nephrology' policy. Periodically, manuscripts are screened for plagiarism and if your manuscript is found to be consistent with what the Editors define $e^{*}$ as plagiarism prior to review of the manuscript then

1) it will be rejected without review and the author(s) notified as such with a chance for rebuttal.

If a manuscript is found to contain evidence of plagiarism after acceptance and/or publication then:

1) the author(s) will be notified, as in the previous situation, and offered a chance for rebuttal.

If the rebuttal arguments are not found to be satisfactory, as judged by the Editors, the manuscript will be rejected and the author sanctioned from publishing additional papers in the Journal for a period to be determined by the Editorial Board. The period of sanction imposed is dependent on the magnitude of plagiarism with a minimum sanction of one year. If a manuscript already published in the Journal is found to exhibit evidence of plagiarism as defined by the Editors ${ }^{\star}$, then we will request a retraction.

${ }^{\star}$ Definition of plagiarism - a $25 \%$ similarity in the Results or Discussion that exactly reproduces another paper.

\section{Arrangement}

Title page: The first page of each paper should indicate the title, the authors' names, the institute where the work was conducted, a short title for use as running head, conflict of interest statement, key words, and word count. Manuscripts are to be double-spaced and formatted using the same font, size 12 throughout text and references.
Full address: The exact postal address of the corresponding author complete with postal code must be given at the bottom of the title page. Please also supply phone and fax numbers, as well as e-mail address.

Key words: Please supply 3-10 key words in English that reflect the content of the paper.

Abstract: Each paper needs an abstract of up to 250 words. It should be structured as follows:

Background/Aims: What is the major problem that prompted the study?

Methods: How was the study performed?

Results: Most important findings?

Conclusion: Most important conclusion?

\section{Footnotes: Avoid footnotes.}

Tables and illustrations: Tables and illustrations (both numbered in Arabic numerals) should be prepared on separate pages. Tables require a heading and figures a legend, also prepared on a separate page. Electronically submitted b/w half-tone and color illustrations must have a final resolution of $300 \mathrm{dpi}$ after scaling, line drawings one of 800-1,200 dpi. Average table $=250$ words

The maximum size of all uploaded files is $40 \mathrm{MB}$.

\section{Color Illustrations}

Online edition: Color illustrations are reproduced free of charge. In the print version, the illustrations are reproduced in black and white. Please avoid referring to the colors in the text and figure legends. Print edition: Up to 6 color illustrations per page can be integrated within the text at CHF 800.- per page.

\section{References}

In the text identify references by Arabic numerals [in square brackets]. Material submitted for publication but not yet accepted should be noted as 'unpublished data' and not be included in the reference list. The list of references should include only those publications which are cited in the text. Do not alphabetize; number references in the order in which they are first mentioned in the text. The surnames of the authors followed by initials should be given. There should be no punctuation other than a comma to separate the authors. Preferably, cite all authors. Abbreviate journal names according to the Index Medicus system. Also see International Committee of Medical Journal Editors: Uniform requirements for manuscripts submitted to biomedical journals (www.icmje.org).

Examples

(a) Papers published in periodicals: Chatel J-M, Bernard $\mathrm{H}$, Orson FM: Isolation and characterization of two complete Ara h 2 isoforms cDNA. Int Arch Allergy Immunol 2003;131:14-18.

(b) Papers published only with DOI numbers:

Theoharides TC, Boucher W, Spear K: Serum interleukin-6 reflects disease severity and osteoporosis in mastocytosis patients. Int Arch Allergy Immunol DOI: $10.1159 / 000063858$

(c) Monographs: Matthews DE, Farewell VT: Using and Understanding Medical Statistics, ed 3, revised. Basel, Karger, 1996.

(d) Edited books: DuBois RN: Cyclooxygenase-2 and colorectal cancer; in Dannenberg AJ, Dubois RN (eds): COX-2. Prog Exp Tum Res. Basel, Karger, 2003, vol 37, pp 124-137.

\section{KARGER}

Fax +41 613061234 E-Mail karger@karger.ch www.karger.com 
Reference Management Software: Use of EndNote is recommended for easy management and formatting of citations and reference lists.

\section{Digital Object Identifier (DOI)}

S. Karger Publishers supports DOIs as unique identifiers for articles. A DOI number will be printed on the title page of each article. DOIs can be useful in the future for identifying and citing articles published online without volume or issue information. More information can be found at www.doi.org.

\section{Supplementary Material}

Supplementary material is restricted to additional data that are not necessary for the scientific integrity and conclusions of the paper. Please note that all supplementary files will undergo editorial review and should be submitted together with the original manuscript. The Editors reserve the right to limit the scope and length of the supplementary material. Supplementary material must meet production quality standards for Web publication without the need for any modification or editing. In general, supplementary files should not exceed $10 \mathrm{MB}$ in size. All figures and tables should have titles and legends and all files should be supplied separately and named clearly. Acceptable files and formats are: Word or PDF files, Excel spreadsheets (only if the data cannot be converted properly to a PDF file), and video files (.mov, .avi, .mpeg).

\section{Author's Choice ${ }^{\mathrm{TM}}$}

Karger's Author's Choice ${ }^{\mathrm{TM}}$ service broadens the reach of your article and gives all users worldwide free and full access for reading, downloading and printing at www.karger.com. The option is available for a onetime fee of CHF 3000.-, which is a permissible cost in grant allocation. More information can be found at www.karger.com/authors_choice.

\section{NIH-Funded Research}

The U.S. National Institutes of Health (NIH) mandates under the NIH Public Access Policy that final, peer-reviewed manuscripts appear in its digital database within 12 months of the official publication date. As a service to authors, Karger submits the final version of your article on your behalf to PubMed Central. For those selecting our premium Author's Choice $^{\mathrm{TM}}$ service, we will send your article immediately upon publishing, accelerating the accessibility of your work without the usual embargo. More details on NIH's Public Access Policy is available at http:// publicaccess.nih.gov/FAQ.htm\#al

\section{Self-Archiving}

Karger permits authors to archive their pre-prints (i.e. pre-refereeing) or post-prints (i.e. final draft post-refereeing) on their personal or institution's servers, provided the following conditions are met: Articles may not be used for commercial purposes, must be linked to the publisher's version, and must acknowledge the publisher's copyright. Authors selecting Karger's Author's Choice ${ }^{\mathrm{TM}}$ feature, however, are also permitted to archive the final, published version of their article, which includes copyediting and design improvements as well as citation links.

\section{Page Charges}

Original Reports exceeding the first 3 printed pages which are free will cost CHF 325.- per extra page. Review papers exceeding the first 6 printed pages which are free will cost CHF 325.- per extra page.

\section{Proofs}

Unless indicated otherwise, proofs are sent to the corresponding author and should be returned with the least possible delay. Alterations made in proofs, other than the correction of printer's errors, as well as corrections after approval to publication, are charged to the author.

\section{Reprints}

Order forms and a price list are sent with the proofs. Orders submitted after the issue is printed are subject to considerably higher prices.

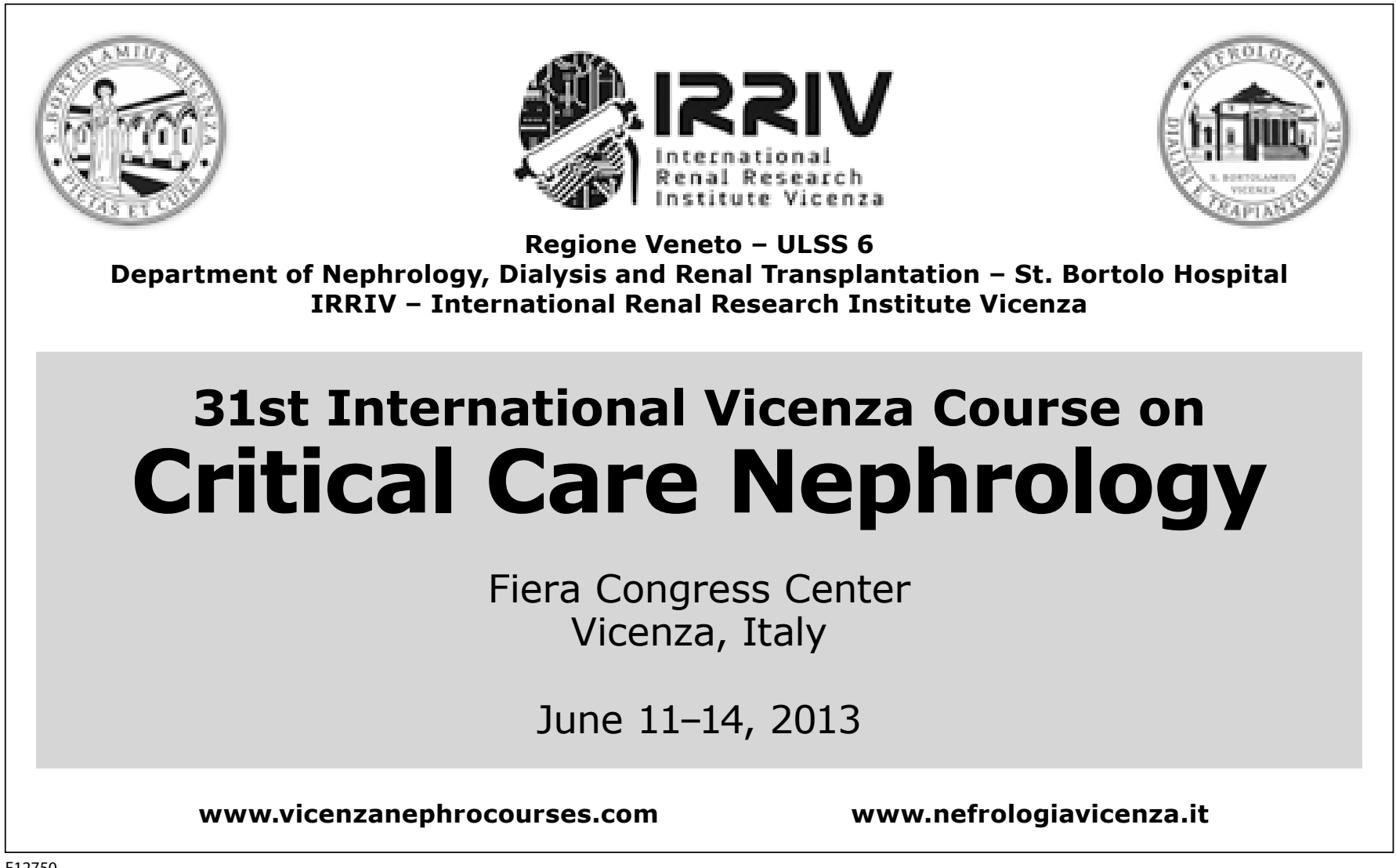

F12750

\section{KARGER}

Fax +41613061234

E-Mail karger@karger.ch

www.karger.com
(C) 2012 S. Karger AG, Basel

The Guidelines for Authors are available at:

www.karger.com/ajn_Guidelines 


\section{Nephrology}

ISSN Print Edition: 0250-8095

ISSN Online Edition: 1421-9670

Journal Homepage: www.karger.com/ajn

Publication Data: 'American Journal of Nephrology' is published 12 times a year. Volumes 35 and 36, each with 6 issues appear in 2012 .

Copyright: (c) 2012 S. Karger AG, Basel (Switzerland). All rights reserved. No part of this publication may be translated into other languages, reproduced or utilized in any form or by any means, electronic or mechanical, including photocopying, recording, microcopying, or by any information storage and retrieval system, without permission in writing from the publisher or, in the case of photocopying, direct payment of a specified fee to the Copyright Clearance Center.

Disclaimer: The statements, opinions and data contained in this publication are solely those of the individual authors and contributors and not of the publisher and the editor(s). The appearance of advertisements in the journal is not a warranty, endorsement, or approval of the products or services advertised or of their effectiveness, quality or safety. The publisher and the editor(s) disclaim responsibility for any injury to persons or property resulting from any ideas, methods, instructions or products referred to in the content or advertisements.
Subscription Rates: Subscriptions run for a full calendar year. Prices are given per year. Personal subscription:

Print or Online

CHF 944.-

EUR 756.-

USD 917.00

Print+Online combined CHF 1040.-

EUR 832.-

USD 1011.00

postage and handling (added to print and print+online)

CHF 81.60 Europe, CHF 120.00 Overseas

EUR 62.40

USD 112.80

Institutional subscription:

Print or Online

Print+Online combined

CHF 4722.

EUR 3778.-

CHF 5194.

USD 4584.00

postage and handling (added to print and print+online)

CHF 102.- Europe, CHF 150.- Overseas

EUR 78.-

USD 141.00

Airmail surcharge: CHF 102.- / USD 96.00
Back Volumes and Single Issues: Information on availability and prices of single print issues and prin or electronic back volumes can be obtained from Customer Service at service@karger.ch.

Bibliographic Indices: This journal is regularly listed in bibliographic services, including Current Contents ${ }^{\circledR}$ and PubMed/MEDLINE.

Photocopying: This journal has been registered with the Copyright Clearance Center (CCC), as indicated by the code appearing on the first page of each article. For readers in the US, this code signals consent for copying of articles for personal or internal use, or for the personal or internal use of specific clients, provided that the stated fee is paid per copy directly to

Copyright Clearance Center Inc

222 Rosewood Drive

Danvers, MA 01923 (USA)

A copy of the first page of the article must accompany payment. Consent does not extend to copying for general distribution, for promotion, for creating new works, or for resale. In these cases, specific written permission must be obtained from the copyright owner,

S. Karger AG, P.O. Box

CH-4009 Basel (Switzerland).
Subscription Orders:

Orders can be placed at agencies, bookstores, directly with the Publisher

\section{S. Karger AG}

Medical and Scientific Publishers

P.O. Box

CH-4009 Basel

Switzerland

(for courier services only:

Allschwilerstrasse 10

$\mathrm{CH}-4055$ Basel)

t: +41613061111

f: +41613061234

e: karger@karger.ch

w: www.karger.com

Change of Address:

Both old and new address should be sent

to the subscription source. or further Karger offices

or representatives:

Germany

S. Karger GmbH

Postfach

79095 Freiburg

Deutschland

(Hausadresse: Wilhelmstrasse 20A

79098 Freiburg)

t: +49761452070

f: +497614520714

e: information@karger.de

w: www.karger.de

Japan

Karger Japan, Inc.

Shiba Daimon Asahi Bldg. $2 \mathrm{~F}$

1-2-23 Shiba Daimon

Minato-ku

Tokyo 105-0012

Japan

t: +81364356242

f: +81364356244

e: publisher@karger.jp

w: www.karger.jp

\section{KARGER}

Fax +41 613061234

E-Mail karger@karger.ch

www.karger.com
(C) 2012 S. Karger AG, Basel

The Journal Home Page is available at:

www.karger.com/ajn
USA

S. Karger Publishers, Inc.

26 West Avon Road

P.O. Box 529

Unionville, CT 06085

USA

Toll free: +18008285479

t: +18606757834

f: +18606757302

e: karger@snet.net

France

Librairie Médi-Sciences Sarl

36, bd de Latour-Maubourg

75007 Paris

France

$\mathrm{t}:+33(0) 145514258$

f. $+33(0) 145560780$

e: librairie@medi-sciences.fr

w: www.medi-sciences.fr

Gulf Council Countries, Iran,

Middle East, North Africa, Turkey

Trans Middle East Internationa

Distribution Co. Ltd. (KaSha)

168 B, King Abdullah the 2nd Street

Daboog Building 2nd Floor

Daboog Area

P.O. Box 2376

Amman 11953

Jordan

t: +962 65153467

f: +96265411336

e: info@kasha.cc

w: www.KaShaoonline.com
South East Asia, China and Taiwan

Karger Regional Office (Malaysia)

CEO Suite Kuala Lumpur

Quill 7, 27th Floor

Jalan Stesen Sentral 5

KL Sentral

Kuala Lumpur 50470

Malaysia

t: +60327766803

f: +60327766999

e: service@karger.cn; r.chew@karger.cn

\section{Karger China}

10th Floor, Twin Towers (East)

B12 Jianguomenwai Avenue

Beijing 100022

China

t: +861051235033

f: +861051235122

e: service@karger.cn; r.chew@karger.cn

w: www.karger.cn

India, Bangladesh, Sri Lanka

Medscience India

Plot No. 17, Yusuf Sarai Market

B.L. Glass Building, 2nd Floor

Sri Aurobindo Marg

New Delhi 110016

India

t: +911146029633

f: +911146029634

c: +919891052128

e: medsci.india@gmail.com 


\section{Contents}

See the journal website for contents

KARGER Basel $\bullet$ Freiburg $\cdot$ Paris $\bullet$ London $\bullet$ New York $\cdot$ New Delhi $•$ Bangkok Beijing $\cdot$ Tokyo $\cdot$ Kuala Lumpur $\cdot$ Singapore $\bullet$ Sydney 


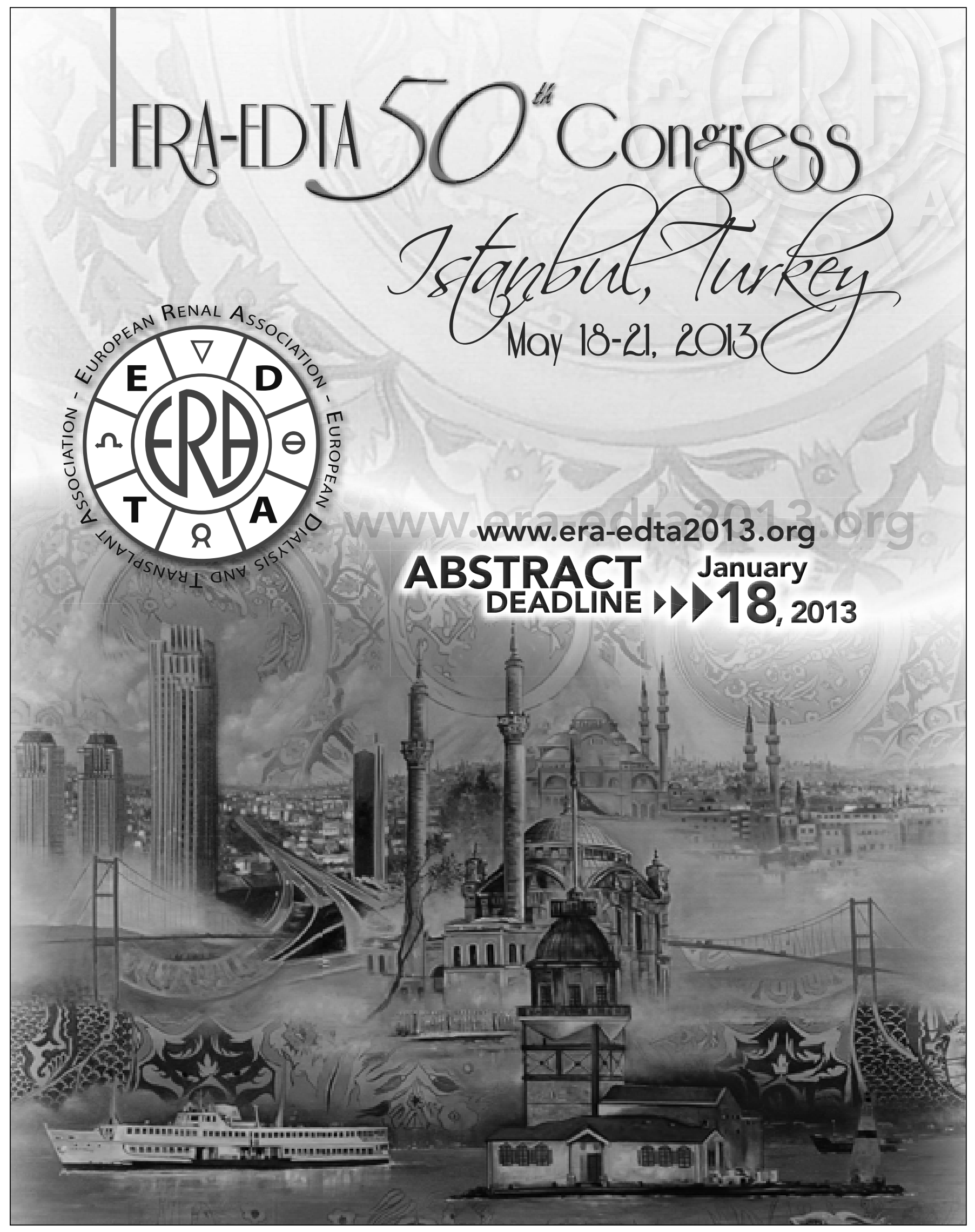




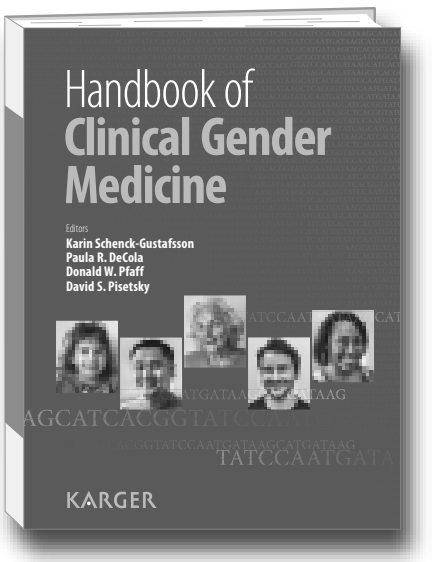

Gender medicine is an important new field in health and disease. It is derived from top-quality research and encompasses the biological and social determinants that underlie the susceptibility to disease and its consequences. In the future, consideration of the role of gender will undoubtedly become an integral feature of all research and clinical care.

Defining the role of gender in medicine requires a broad perspective on biology and diverse skills in biomedical and social sciences. When these scientific disciplines come together, a revolution in medical care is in the making. Covering twelve different areas of medicine, the practical and useful 'Handbook of Clinical Gender Medicine' provides up-to-date information on the role of gender in the clinical presentation, diagnosis, and management of a wide range of common diseases.

The contributing authors of this handbook are all experts who, in well-referenced chapters, cogently and concisely explain how incorporation of gender issues into research can affect the medical understanding and treatment of heart disease, osteoporosis, arthritis, pain, violence, and malaria among other conditions. This intriguing and unique medical textbook provides readers with a valuable new perspective to understand biology and incorporate gender issues into the different branches of medicine.

\section{Handbook of Clinical Gender Medicine}

\author{
Editors \\ Karin Schenck-Gustafsson \\ Paula R. DeCola \\ Donald W. Pfaff \\ David S. Pisetsky
}

\section{Contents}

Foreword: Wainer, J.; Wainer, Z.

Preface: Schenck-Gustafsson, $\boldsymbol{K}$.

\section{Introduction}

Gender Matters: Wainer, J.; Wainer, $\mathbf{Z}$.

Biological Sex and the Genome: What Makes

Us Ourselves? Legato, M.J.

\section{Social and Biological Determinants in \\ Health and Disease}

Section Editors: DeCola, P.R.; Schober, J.M.

\section{Central Nervous System and}

\section{Clinical Applications}

Section Editor: Pfaff, D.W.

\section{Neurology}

Section Editor: Olsson, $\boldsymbol{T}$.

Pain

Section Editor: Murphy, A.Z.

\section{Circulation}

Section Editor: Schenck-Gustafsson, $\boldsymbol{K}$

\section{Cancer}

Section Editor: Gustafsson, J.-Å.

\section{Metabolic Disease}

Section Editor: Werner, $\boldsymbol{s}$.

Autoimmune, Inflammatory, and

Musculoskeletal Disease

Section Editor: Pisetsky, D.S.

\section{Infectious Diseases}

Section Editor: Britton, $\mathbf{S}$.

\section{Urology, Sexual Dysfunction,}

and Nephrology

Section Editor: Arver, $\mathbf{S}$.

\section{Pharmaceutical Drugs}

Section Editor: Parekh, $\boldsymbol{A}$.

\section{Geriatrics}

Section Editor: Herlitz, $\boldsymbol{A}$.

\section{KARGER}

Please see the full contents on:

www.karger.com/gender_medicine

Handbook of Clinical Gender Medicine Editors: Schenck-Gustafsson, K. (Stockholm):

DeCola, P.R.; Pfaff, D.W. (New York, N.Y.); Pisetsky, D.S. (Durham, N.C.)

$\mathrm{XVI}+522$ p., 62 fig., 4 in color, 63 tab., soft cover, 2012 CHF 69.- / EUR 51.- / USD 69.00

Prices subject to change

EUR price for Germany, USD price for USA only

ISBN 978-3-8055-9929-0

e-ISBN 978-3-8055-9930-6 $\longrightarrow$ Please send: __ copy/ies

$\varepsilon$

Postage and handling free with prepayment

Payment:

Please charge to my credit card

- $\square$ American Express $\square$ Diners

ᄂ $\square$ MasterCard $\square$ Visa

Card No.

ט

Exp. date:

CVV/CVC

( 3 digits in the signature field on the back of Visa and MasterCard)

$\square$ Check enclosed $\quad \square$ Please bill me

Orders may be placed with any bookshop, subscription agency, directly with the publisher or through a Karger distributor.
Fax: +41613061234

S. Karger AG, P.O. Box, CH-4009 Basel (Switzerland)

E-Mail orders@karger.ch, www.karger.com

Name/Address: 


\title{
A compendium of basic principles and clinical practice
}

\section{Peritoneal Dialysis - State-of-the-Art 2012}

\author{
Editors \\ Claudio Ronco \\ Mitchell H. Rosner \\ Carlo Crepaldi
}

\section{Main Headings}

- Peritoneal Dialysis Solutions

- New Challenges for PD and Home Therapies

- Practical Issues in Peritoneal Dialysis 1

- Telemedicine and e-Health in PD

- Lipid Disorders, Inflammation and Anemia

- CKD-MBD and Inflammation Management in PD

- Fluid Overload and Cardiovascular Events

- Practical Issues in Peritoneal Dialysis 2

- Peritoneal Dialysis Technology

- Peritonitis and Other Clinical Outcomes

This publication contains the most recent findings in the field as presented by the outstanding faculty of the 2012 International Vicenza Course on Peritoneal Dialysis. After 30 years, this course is still one of the main educational events in the field of peritoneal dialysis as well as other disciplines including CKD, hemodialysis and critical care nephrology. The publication of the book in time for the course represents another success of the Vicenza team. The experts of the world and the related industry met in Vicenza for this important anniversary which is celebrated by this book representing not only a milestone in the history of the Department of Nephrology and the International Renal Research Institute of Vicenza, but also and above all an extraordinary educational tool for all physicians and nurses interested in peritoneal dialysis today.

\section{Contributions to Nephrology, Vol. 178}

Series Editor: Ronco, C. (Vicenza)

ISSN 0302-5144 / e-ISSN 1662-2782

Peritoneal Dialysis - State-of-the-Art 2012

Editors: Ronco, C. (Vicenza); Rosner, M.H.

(Charlottesville, Va.); Crepaldi, C. (Vicenza)

XIV + 292 p., 28 fig., 2 in color, 30 tab., hard cover, 2012

CHF 228. - / EUR 190.- / USD 268.00

Prices subject to change

EUR price for Germany, USD price for USA only

ISBN 978-3-318-02162-2

e-ISBN 978-3-318-02163-9

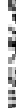

\section{$\longrightarrow$ Please send: __ copy/ies}

$\varepsilon$

Postage and handling free with prepayment

Payment:

Please charge to my credit card

- $\square$ American Express $\square$ Diners

$\square$ MasterCard $\square$ Visa

- Card No.:

o

ช

- CVV/CVC

(3 digits in the signature field on the back of Visa and MasterCard)

$\square$ Check enclosed $\quad \square$ Please bill me

Orders may be placed with any bookshop, subscription agency, directly with the publisher or through a Karger distributor.
Fax: +41 613061234

S. Karger AG, P.O. Box, $\mathrm{CH}-4009$ Basel (Switzerland) E-Mail orders@karger.ch, www.karger.com

Name/Address: 


\section{Research advances at the interface of cardiology and nephrology}

\section{CardioRenal Medicine}

\section{Editor}

J.R. Sowers, Columbia, Mo.

Assistant Editor

B. Hunter, Columbia, Mo.
Associate Editors

M. Bursztyn, Jerusalem

S. Brietzke, Columbia, Mo.

K.C. Dellsperger,

Columbia, Mo.

J.P. Dwyer, Nashville, Tenn.

K.C. Ferdinand, Atlanta, Ga.

M.R. Hayden,

Camdentown, Mo.
E.J. Henriksen, Tucson, Ariz.

J.M. Luther, Nashville, Tenn.

A.R. Parrish, Columbia, Mo.

N. Stern, Tel Aviv

C.S. Stump, Tucson, Ariz.

\section{A.T. Whaley-Connell,}

Columbia, Mo.

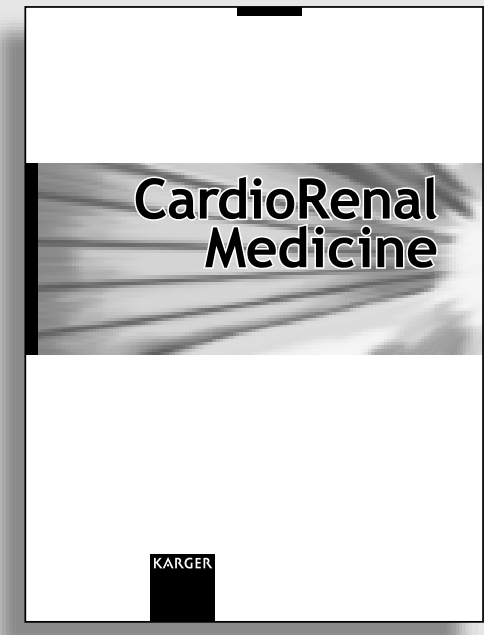

More information at

\section{www.karger.com/crm}

- Pay-per-View and Subscriber Access

to Full Text

- Full Table of Contents

- Full Editorial Board

- Free Abstracts and Selected Articles

- Online Sample Issue

- Submission/Guidelines for Authors

- Subscription Details

- Free Alert Service

- Online Library Recommendation

\section{Selected contributions}

- Renal Dysfunction in the Presence of Normoalbuminuria in Type 2 Diabetes:

Results from the DEMAND Study: Dwyer, J.P. (Nashville, Tenn.); Parving, H.-H.

(Copenhagen/Aarhus); Hunsicker, L.G. (lowa City, lowa); Ravid, M. (Tel Aviv); Remuzzi, G. (Bergamo); Lewis, J.B. (Nashville, Tenn.) for the DEMAND Investigators

- The Relationship between Epicardial Adipose Tissue and Coronary Artery

Calcification in Peritoneal Dialysis Patients: Turkmen, K.; 0zbek, 0.; Kayikcioğlu, H.;

Kayrak, M.; Solak, Y.; Nayman, A.; Anil, M.; Babur, H.; Tonbul, H.Z. (Meram)

- Gestational Diabetes and the Offspring: Implications in the Development of the

Cardiorenal Metabolic Syndrome in Offspring: Garcia-Vargas, L.; Addison, S.S.;

Nistala, R.; Kurukulasuriya, D.; Sowers, J.R. (Columbia, Mo.)

- Mitochondria and Oxidative Stress in the Cardiorenal Metabolic Syndrome:

Aroor, A.R.; Mandavia, C. (Columbia, Mo.); Ren, J. (Laramie, Wyo.); Sowers, J.R.; Pulakat, L.

(Columbia, Mo.)

- The Cardiorenal Syndrome: Basis and Common Ground for a Multidisciplinary

Patient-Oriented Therapy: Ronco, C. (Vicenza)

- Interaction between Adiponectin and Aldosterone: Flynn, C.; Bakris, G.L. (Chicago, III.)

- Hypertensive Cardiovascular and Renal Disease and Target Organ Damage:

Lessons from Animal Models: Susic, D.; Frohlich, E.D. (New Orleans, La.)

- The ADMA-Metformin Hypothesis: Linking the Cardiovascular Consequences of the Metabolic Syndrome and Type 2 Diabetes: Bestermann, W.H. Jr. (Kingsport, Tenn.)
CardioRenal Medicine

2013: Vol. 3

4 issues per volume

Language: English

ISSN: 1664-3828 (print)

e-ISSN: 1664-5502 (online)
The journal of CardioRenal Medicine explores the mechanisms by which obesity and other metabolic abnormalities promote the pathogenesis and progression of heart and kidney disease (cardiorenal metabolic syndrome). It provides an interdisciplinary platform for the advancement of research and clinical practice, focussing on translational issues.

Attention is paid to the fact that some metabolic abnormalities cluster with heart and chronic kidney disease, and collectively this is called the cardiorenal metabolic syndrome. Moreover, certain metabolic abnormalities of the heart promote impaired coronary artery endothelial function, diastolic dysfunction and ischemic reconditioning that parallel glomerular hyperfiltration and impairments in proximal tubule handling of sodium and albumin. Another point of focus is the role of the obesity epidemic in promoting the increasing incidence of heart and kidney disease in industrialized countries and the prevailing problems of insufficient exercise and excessive consumption of cheap, unwholesome food in promotion of the cardiorenal metabolic syndrome in both adults and children.

CardioRenal Medicine addresses a multidisciplinary audience consisting of nephrologists, cardiologists, nutritionists, endocrinologists, physiologists and general internists 


\section{Fastest publication following acceptance in nephrology}

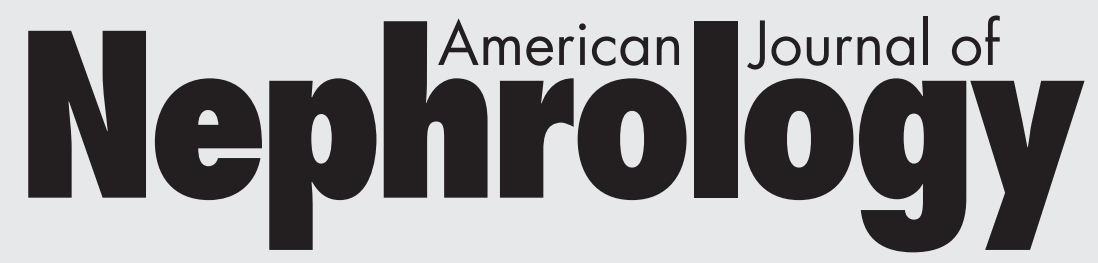

Managing Editor

G. Bakris, Chicago, III.
Associate Editors

R. Agarwal,

Indianapolis, Ind.

R.J. Glassock, Laguna Niguel, Calif.

B. Palmer, Dallas, Tex.

S. Sprague, Evanston, III.

M. Weir, Baltimore, Md.

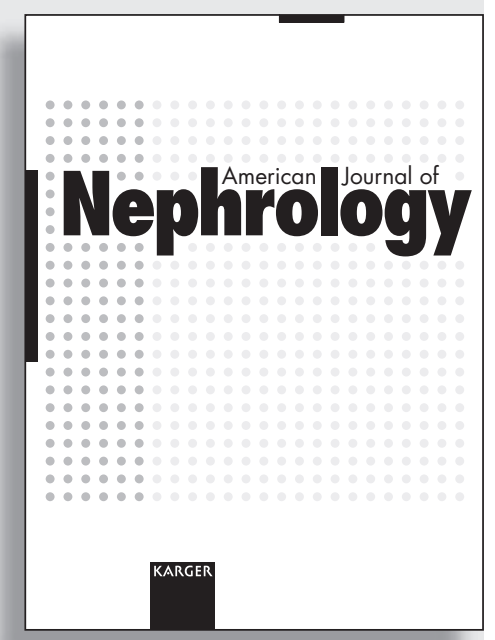

More information at

www.karger.com/ajn

- Pay-per-View and Subscriber Access to Full Text

- Full Table of Contents

- Full Editorial Board

- Free Abstracts and Selected Articles

- Online Sample Issue

- Submission/Guidelines for Authors

- Subscription Details

- Free Alert Service

- Online Library Recommendation

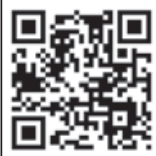

American Journal of Nephrology 2013: Volumes 37,38

6 issues per volume

Language: English

ISSN 0250-8095 (print)

ISSN 1421-9670 (online)

Listed in bibliographic services, including Current Contents ${ }^{\circ}$, MEDLINE, Biological Abstracts, EMBASE/Excerpta Medica

\section{Selected contributions}

- Renal Adaptation to Gentamicin-Induced Mineral Loss: Lee, C.-T.; Chen, H.C.; Ng, H.-Y. (Kaohsiung); Lai, L.-W.; Lien, Y.-H.H. (Tucson, Ariz.)

- Renal Biopsy in Very Elderly Patients: Data from the Spanish Registry of Glomerulonephritis: Verde, E.; Quiroga, B. (Madrid); Rivera, F. (Ciudad Real); López-Gómez, J.M. (Madrid) on behalf of all the members of the Spanish Registry of Glomerulonephritis

- Effects of Cinacalcet in Renal Transplant Patients with Hyperparathyroidism: Courbebaisse, M.; Diet, C.; Timsit, M.-0.; Mamzer, M.-F.; Thervet, E.; Noel, L.-H.; Legendre, C.; Friedlander, G.; Martinez, F.; Prié, D. (Paris)

- Tacrolimus Improves the Proteinuria Remission in Patients with Refractory IgA Nephropathy: Zhang, Q.; Shi, S.; Zhu, L.; Lv, J.; Liu, L.; Chen, Y.; Zhang, H.; Wang, H. (Beijing)

- Evidence in Favor of a Severely Impaired Net Intestinal Calcium Absorption in Patients with (Early-Stage) Chronic Kidney Disease: Viaene, L.; Meijers, B.K.I.; Vanrenterghem, Y.; Evenepoel, P. (Leuven)

- Clinical Grand Rounds: Atypical Hemolytic Uremic Syndrome: Hodgkins, K.S.; Bobrowski, A.E.; Lane, J.C.; Langman, C.B. (Chicago, III.)

- Anti-Infective Locks for Treatment of Central Line-Associated Bloodstream Infection: A Systematic Review and Meta-Analysis: 0'Horo, J.C.; Silva, G.L.M. (Milwaukee, Wisc.); Safdar, N. (Madison, Wisc.)

- The Oxford Classification of IgA Nephropathy: A Retrospective Analysis: Yau, T.; Korbet, S.M.; Schwartz, M.M.; Cimbaluk, D.J. (Chicago, III.)
The American Journal of Nephrology is a peerreviewed journal that focuses on timely topics in both basic science and clinical research. Papers are divided into several sections, including:

- Original reports, spanning clinical, basic and outcomes research

- In-depth topic reviews on specific topics selected by the Editor and Associate Editors and invited

- Debates-selected on 'hot topics' determined by the editorial board

Responding to the ever increasing pace in research, the American Journal of Nephrology adheres to a very tight publication schedule: accepted papers appear online within 5-6 weeks of acceptance. 


\section{Nephrology}

In-Depth Topic Review

261 Tumor Necrosis Factor Receptors: Biology and Therapeutic Potential in Kidney Diseases

Speeckaert, M.M.; Speeckaert, R.; Laute, M.; Vanholder, R.; Delanghe, J.R. (Ghent)

Original Report: Transplantation

201 Seasonal Maintenance of Influenza Vaccine-Induced Antibody Response in Kidney Transplant Recipients Birdwell, K.A.; Ikizler, M.R.; Wang, L.; Byrne, D.W.; Sannella, E.C. (Nashville, Tenn.); Wright, P.F. (Lebanon, N.H.); Ikizler, T.A. (Nashville, Tenn.)

Original Reports: Laboratory Investigation

208 Treatment with a Novel Hypoxia-Inducible Factor Hydroxylase Inhibitor (TRC160334) Ameliorates Ischemic Acute Kidney Injury

Jamadarkhana, P.; Chaudhary, A.; Chhipa, L.; Dubey, A.; Mohanan, A.; Gupta, R.; Deshpande, S. (Gandhinagar)

252 Relevance of the ACTN4 Gene in African-Americans with Non-Diabetic End-Stage Renal Disease

Bostrom, M.A. (Kannapolis, N.C.); Perlegas, P.; Lu, L.; Hicks, P.J.; Hawkins, G.; Ng, M.C.Y.; Langefeld, C.D.; Freedman, B.I.; Bowden, D.W. (Winston-Salem, N.C.)

278 Parstatin Prevents Renal Injury following Ischemia/ Reperfusion and Radiocontrast Administration

Diamantopoulos, A.; Kyriazis, I.; Geronatsiou, K.; Papadaki, H. (Rio-Patras); Loudos, G. (Athens); Kagadis, G.C.; Katsanos, K.; Liatsikos, E.; Karnabatidis, D.; Siamblis, D.; Tsopanoglou, N.E. (Rio-Patras)
Original Reports: Patient-Oriented, Translational Research

219 Obesity, Anthropometric Measures and Chronic Kidney Disease Complications

Navaneethan, S.D.; Kirwan, J.P.; Arrigain, S.; Schreiber, M.J. (Cleveland, Ohio); Sarnak, M.J. (Boston, Mass.); Schold, J.D. (Cleveland, Ohio)

228 Relationship between Serum Magnesium Levels and Cardiovascular Events in Chronic Kidney Disease Patients

Kanbay, M.; Yilmaz, M.I. (Ankara); Apetrii, M. (Iasi); Saglam, M.; Yaman, H.; Unal, H.U.; Gok, M.; Caglar, K.; Oguz, Y.; Yenicesu, M.; Cetinkaya, H.; Eyileten, T.; Acikel, C.; Vural, A. (Ankara); Covic, A. (Iasi)

238 Impact of Long-Term Cinacalcet, Ibandronate or Teriparatide Therapy on Bone Mineral Density of Hemodialysis Patients: A Pilot Study

Mitsopoulos, E.; Ginikopoulou, E.; Economidou, D. (Thessaloniki); Zanos, S. (Seattle, Wash.); Pateinakis, P. Minasidis, E.; Memmos, D. (Thessaloniki); Thodis, E.; Vargemezis, V. (Alexandroupolis); Tsakiris, D. (Thessaloniki)

245 Risk Factor, Age and Sex Differences in Chronic Kidney Disease Prevalence in a Diabetic Cohort: The Pathways Study

Yu, M.K.; Lyles, C.R.; Bent-Shaw, L.A.; Young, B.A. (Seattle, Wash.); and the Pathways Authors

271 The Combination of Mycophenolate Mofetil with Corticosteroids Induces Remission of Henoch-Schönlein Purpura Nephritis

Ren, P.; Han, F.; Chen, L.; Xu, Y.; Wang, Y.; Chen, J. (Hangzhou)

287 The Impact of Chronic Obstructive Pulmonary Disease and Smoking on Mortality and Kidney Transplantation in End-Stage Kidney Disease

Kent, B.D. (Donegal/Dublin); Eltayeb, E.E.; Woodman, A.; Mutwali, A.; Nguyen, H.T. (Donegal); Stack, A.G. (Limerick) 